\title{
Europe's Ius Commune on Director Revocability
}

\author{
by
}

SOFie Cools*

This article argues that a mandatory rule of at will revocability of company directors is typical of European civil law. The article shows that the rule is widely spread on the European continent, but not as a result of harmonization efforts of the European Union. Instead, the rule has its historical foundations in the early development of French law. It first appeared as a general rule in Napoleon's codification of commercial law and subsequently extended to the other major jurisdictions in the French and German civil law family. Despite some tempering of the rule, especially in the German legal tradition, it still plays an important role in European civil law jurisdictions. In traditional common law, in contrast, the rule is extraneous. It did not appear in old common law, was merely a default rule when first introduced in the United Kingdom, and is still not mandatory in the United States. These novel findings shed important light on some other differences in company law, and possibly also in prevailing stock ownership structures, between civil law and common law jurisdictions, and thus lay a promising basis for further research.

Table of Contents

ECFR 2011, 199-234

Introduction . . . . . . . . . . . . . . . . . . . . 200

I. Definition and Importance of At Will Revocability . . . . . . . . . . . . . . . . 201

1. Definition . . . . . . . . . . . . . . . . . . . 201

2. Importance . . . . . . . . . . . . . . . . . 202

II. Occurrence in Continental Europe . . . . . . . . . . . . . . . . . . . . 206

1. At Will Revocability in Single-Tier Boards . . . . . . . . . . . . . . 206

2. A Watered-Down Version in Most Two-Tier Boards . . . . . . . . . . . . 209

III. European Union Law on the Sidelines . . . . . . . . . . . . . . . . . . . 217

1. Absence of Regulation by European Union . . . . . . . . . . . . . . . 217

2. The Case of Switzerland . . . . . . . . . . . . . . . . . . . 220

IV. The Origins of the Mandatory Rule of At Will Revocability . . . . . . . . . 221

1. The Development of At Will Revocability in France . . . . . . . . . 222

2. The Proliferation of At Will Revocability in Continental Europe . . . 224

* S.J.D. Candidate Harvard Law School; PhD Researcher Catholic University of Louvain; $\mathrm{PhD}$ Fellow Research Foundation Flanders. An earlier draft of this article was presented at the annual symposium of the European Company and Financial Law Review held in Brussels on October 1, 2010. I would like to thank Professors Sabrina Bruno, Martin Gelter, Maarten Kroeze and Markus Roth, as well as Drs. Jane Bestor, Jennifer Payne and Stefan Kramer for their helpful comments. 
V. The Lower Significance of Revocability in Common Law . . . . . . . . 229

1. The United Kingdom . . . . . . . . . . . . . . . . . . . . . . . 229

2. The United States . . . . . . . . . . . . . . . . . . . 230

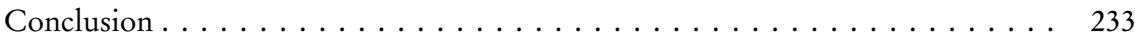

\section{Introduction}

The most important voting right of shareholders is probably the right to elect and dismiss directors. The election of directors has been called "the ideological underpinning upon which the legitimacy of directorial power rests." ${ }^{1}$ It usually garners a lot of attention among scholars and policymakers. The same has not been true for the right to dismiss directors, although it is at least of equal concern. This article therefore explores the neglected topic of the latitude of shareholders meetings to remove directors of public companies over time and across several jurisdictions in Europe and the United States. The specific question is whether the law mandatorily prescribes that shareholders have the right to remove directors at will, and whether a general principle can be distilled at a regional or international level. The analysis is restricted to the law applicable to companies with publicly traded stock.

Part II of this article starts off with an inquiry into the current scope of the rule of at will dismissal of company directors on the European continent. The rule is usually applied more vigorously in single-tier boards than in dual-tier boards. There is a markedly strict mandatory rule of at will removal in a few Frenchorigin jurisdictions with a one-tier board, such as France and Belgium. As is wellknown, Germany, Austria and in some cases the Netherlands impose a two-tier board structure. Although the rule of at will removal has been significantly impaired for these dual tier boards, this article shows that it still plays a vital role.

Readers might conjecture that this commonality across the jurisdictions examined might result from European Union regulation. Part III therefore examines whether the European Union has taken any initiatives in this field and whether at will removal of directors is equally important in European countries that are not member of the European Union. Because no influence from the European Union can be detected, Part IV unravels the origins of at will revocability of directors in the civil law tradition. It finds that at will revocability was first explicitly stated as a general and mandatory rule in Napoleon's Code de Commerce of 1807. Together with the Napoleonic codes, it spread out over continental Europe. Without taking a position in debates over the future of private law in Europe, I thus argue that at will revocability can be rated among the common principles, or ius commune in a modern sense, of European civil law.

1 Blasius Indus., Inc. v. Atlas Corp., 564 A.2d 651, 659 (Del. Ch. 1988). 
In contrast, the analysis reveals that traditional common law did not feature the principle of at will revocability. Surprisingly, this discrepancy between common law and European civil law has so far been largely overlooked in legal and economic scholarship. Part V therefore takes a look at the current situation and history in the United Kingdom and the United States. Whereas the former has over time adopted a compulsory rule of at will revocability, the latter have not. Despite recent efforts to enhance the position of stockholders in American companies, they still usually only have limited power to remove directors.

These findings do not support the conclusion that directors of continental European companies live in great uncertainty. They often put other means to use, such as procedural rules relating to shareholders meetings or techniques derived from labor law, in order to complicate their revocation by the shareholders meeting or to obtain indemnification should they effectively be dismissed. Another source of safety lies in the appointment by a controlling shareholder. Because of the presence of a controlling shareholder, no new controlling shareholder or temporary coalition can then arise and remove the director. Consequently, he does not have to fear removal as long as he is the controlling shareholder, or faithfully complies with the controller's wishes. The conclusion suggests how, along these lines, the divergence between common law and European civil law with regard to director removal may contribute to our understanding of, among others, why stock ownership is predominantly dispersed in the former and concentrated in the latter. Introducing the findings of this article in comparative research is therefore bound to yield interesting new insights, especially with regard to differences between civil and common law.

\section{Definition and Importance of At Will Revocability}

\section{Definition}

This article investigates how prevalent a mandatory rule of at will revocability is internationally and historically. This encompasses first the question of whether the shareholders meeting or, in some cases, a body appointed by it, has the power to remove directors at will. At will revocability is often termed "ad nutum" revocability. "Ad nutum" is Latin for "at will" or, literally, "at a nod". ${ }^{2}$ In a figurative sense, a nod is all it takes to remove a director under a rule of at will revocability. The second part of the question is whether the law sets out the rule of at will removal in a mandatory way. In that event, shareholders derive their right to dismiss directors at will directly from the statute,

2 Nutus (m.): nod; command, will. 
and companies are not allowed to encroach upon any aspects of this right - in their articles of association or elsewhere.

When at will revocability is applicable to its fullest extent, four key components can be distinguished. First, "at will” means that the shareholders meeting can oust incumbent directors at any time. In other words, they are not obliged to wait until the annual general meeting and can proceed to the removal in an extraordinary general meeting. ${ }^{3}$ Second, if shareholders can truly remove directors at will, they do not need to show a good cause for removal. In fact, they do not need to mention any cause at all, and often it is considered prudent not to do so. This condition bears on the third component of at will removal, namely that removal cannot in itself trigger any duty to pay an indemnification or termination fee. But at will revocability is not an authorization to be rude. Libel or insults made in the course of the removal procedure normally imply a fault under civil law rules, for which damages are due. That is not inconsistent with the rule of ad nutum revocability.

The three elements listed above are part of the traditional definition of at will removability. ${ }^{4}$ As the following analysis will show, a fourth condition must be added to this list, namely that the shareholders meeting is allowed to remove any number of directors at the same time..$^{5}$ If removal is possible only for a certain number of directors or for the entire board, the shareholders meeting can no longer be said to freely exercise its will.

\section{Importance}

The legal and economic importance of the power to remove directors at will is considerable. On a legal level, it includes not only the consequences that the law explicitly attaches to it, such as nullity of charter or contract provisions entered into by the company that impinge on removability, limitations on directors' ability to enter into an employment agreement with the company etc. ${ }^{6}$ The importance of other legal provisions is also affected, especially those

3 The focus here is on the substantive requirements. Procedural aspects, such as the power to convene an extraordinary meeting or to add an item to the agenda or the company's proxy, fall outside the scope of this article.

4 Only few authors have attempted to define the concept of at will revocability. E.g. Alain François et al., Omgaan met conflicten in vennootschappen: regeling van geschillen is meer dan geschillenregeling, in OMGAAN MET CONFLICTEN IN DE VENNOOTSCHAP 39 (Koen Byttebier et al. eds., 2009); Maurice Cozian et al., Droit des sociétés 357 (21 $1^{\text {st }}$ ed. 2008).

5 See infra, Part II.2(i).

6 Eddy Wymeersch, A Status Report on Corporate Governance Rules and Practices in Some Continental European States, in Comparative Corporate Governance. The State 
related to the distribution of power within corporations. Directors can appear enormously powerful when they have the right to amend the corporate charter and to decide on reincorporation, mergers, acquisitions, and the sale of substantially all assets and distributions. Yet, power can shift perceptibly depending on the rules governing appointment and dismissal of directors. If a board with broad substantive powers is in fact re-electing itself and does not need to fear removal, it can run the company as a despot. If, in contrast, the shareholders meeting freely appoints and dismisses directors, the situation is different. The power to sack directors at any time with no need for justification serves as an ultimate stick for shareholders who disagree with the board's decisions - even if those decisions, strictly speaking, are within the latter's exclusive competence.

In a similar vein, at will revocability affects two agency problems. First, it mitigates the so-called "first agency problem" caused by the separation of decision and risk-bearing functions between board (and management), on the one hand, and small shareholders, on the other hand. ${ }^{8}$ Whenever the interests of the directors are not perfectly aligned with those of the shareholders, the directors may be tempted to serve their private interests and thus display suboptimal corporate performance. Shareholders' power to remove directors is a major tool for tackling the first agency problem. ${ }^{9}$ Lifting all or most

of the Art and Emerging Research 1044, 1092-93 (Klaus J. Hopt et al. eds., 1998). See, for Belgium: Didier Willermain, Le statut de l'administrateur de sociétés anonymes: principes, questions et réflexions, 107 Revue Pratique des Sociétés (207) 251-52 (2008).

7 In some respects, however, at will removal can also magnify the first agency problem. The insecurity of his position can allegedly lead a director to overinvest in short-term projects, or to display excessive risk-aversion (see Jeremy C. Stein, Takeover Threats and Managerial Myopia, 96 J. Pol. Econ. 61 (1988)). Easy removal of directors may also jeopardize the continuity of a firm's management (see Richard H. Koppes et al., Corporate Governance Out of Focus: The Debate Over Classified Boards, 54 Bus. LAw. 1023, 1051-52 (1999)). If limited removability allows directors to extract better terms in case of a takeover (Robert Comment \& G. William Schwert, Poison or Placebo? Evidence on the Deterrence and Wealth Effects of Moderns Antitakeover Measures, 39 J. Fin. Econ. 3 (1995)), then these benefits are lost in a system of at will removal. However, several prominent scholars argue that the incumbents generally do not use their leverage for the shareholders' benefit: Lucian Arye Bebchuk, The Case Against Board Veto in Corporate Takeovers, 69 U. CHI. L. Rev. 973, 1007-10 (2002); John C. Coates IV, Takeover Defenses in the Shadow of the Pill: A Critique of the Scientific Evidence, 79 TEx. L. Rev. 271, 337 (2000); John C. Coates IV, Empirical Evidence on Structural Takeover Defenses: Where Do We Stand?, 54 U. Miami L. Rev. 783, 794-96 (2000).

8 Adolf A. Berle Jr. \& Gardiner C. Means, The Modern Corporation and Private Property 2-3 (1933); John Armour et al., Agency Problems and Legal Strategies, in The Anatomy of Corporate Law 39, 42 (Reinier Kraakman et al., $2^{\text {nd }}$ ed. 2009).

9 Armour et al., supra note 8, at 39-44. 
conditions for using the right of removal obviously reinforces the efficacy of such a right. Its effects are in the first place preventive, in that directors are more likely to act in accordance with the shareholders' wishes in the face of a credible threat of removal, be it independently or in the context of a takeover. At will revocability indeed enhances the strength of the takeover threat by barring certain entrenchment devices and thus aggravating the expected consequences for the incumbents and its appeal to candidate acquirers. If prevention fails, effective removal can serve as a remedy. ${ }^{10}$ Empirical evidence abounds that some entrenchment techniques that would not be allowed under a mandatory rule of at will revocability reduce the chances of success of takeover bids ${ }^{11}$ (which are often associated with increased shareholder wealth), ${ }^{12}$ render the successful bids less efficient, ${ }^{13}$ and, outside the takeover context, are associated with lower firm valuation and performance. ${ }^{14}$

Second, at will revocability intensifies the "second agency problem," which stems from the divergence of interests between controlling shareholders and minority shareholders when stock ownership is not fully dispersed. As mentioned before, at will revocability enables the shareholders meeting to influence the management of the corporation. In the presence of a large shareholder

10 See Henry G. Manne, Mergers and the Market for Corporate Control, 73 J. Pol. Econ. 110, 112-14 (1965).

11 E.g. Lucian Bebchuk et al., The Powerful Antitakeover Force of Staggered Boards: Theory, Evidence, and Policy, 54 STAN. L. Rev. 887 (2002). The combination of an effective staggered board (which flies in the face of at will revocability) with a poison pill makes it almost chanceless an undertaking to replace the board through a hostile bid. A staggered board is characterized as an "effective staggered board" if a staggered board "is installed in the charter, directors may only be removed for cause, and shareholders may not 'pack the board' by increasing the number of directors and filling the vacancies created" (id. at 894 , emphasis added).

12 E.g. Lisa F. Borstadt \& Thomas J. Zwirlein, The Efficient Monitoring Role of Proxy Contests: An Empirical Analysis of Post-Contest Control Changes and Firm Performance, 21(3) Fin. Mgmt. 22 (1992); J. Harold Mulherin \& Annette B. Poulsen, Proxy Contests and Corporate Change: Implications for Shareholder Wealth, $47 \mathrm{~J}$. Fin. Econ. 279 (1998).

13 When incumbents are difficult to remove, their bargaining power in negotiations with insurgents increases, which they can use to extract personal benefits. See e.g. Lucian A. Bebchuk, The Case Against Board Veto in Corporate Takeovers, 3 U. CHI. L. Rev. 973, 991 (2002); Jay Hartzell et al., What's in it for Me? Personal Benefits Obtained by CEOs Whose Firms are Acquired, 17 Rev. Fin. ST. 37 (2004). See supra, note 6.

14 E.g. Bebchuk et al., supra note 11 (staggered boards are associated with lower firm value); Lucian Bebchuk \& Alma Cohen, The Costs of Entrenched Boards, 78 J. FIn. Econ. 409 (2005) (idem); Lucian Bebchuk et al., What Matters in Corporate Governance?, 22 Rev. FIN. ST. 783 (2009) (entrenchment, among others by means that are irreconcilable with at will removability, correlates with lower corporate performance and firm valuation). 
or group of shareholders who dominate the shareholders meeting, this ability to interfere in management is effectively exercised by the largest shareholder(s) rather than by the shareholders meeting as a whole. This situation opens up possibilities for expropriation and tunneling, etc. ${ }^{15}$ Empirical evidence shows that these pernicious effects are especially strong where shareholder protection is weak. ${ }^{16}$

At will removability of directors, one can conclude, limits directors' relative independence within the corporation, thereby mitigating their failure to align with shareholder interests while exacerbating the potential for conflicts of interest among controlling and minority shareholders. Stated differently, it plays a positive role in jurisdictions where corporations are primarily plagued by the first agency problem - typically those with diffuse stock ownership and possibly a negative role where the second agency problem dominates necessarily characterized by concentrated stock ownership. More than that, one could theorize that there is some causality to this relationship. ${ }^{17}$ Arguably, a mandatory rule of at will removability virtually precludes the coming into existence of the first agency problem, because it does not allow the board to act independently from the shareholders meeting. The absence of a mandatory rule of at will removability, conversely, does allow this to happen. Similarly, at will removability of directors could stimulate the concentration of stock ownership with its concomitant second agency problem. Indeed, under a mandatory rule of at will removability, the ownership of a large amount of stock is necessary to maintain control over the firm's management. However, such a rule could not only be one of the causes, but also a consequence of the existence of controlling stockholders. By lobbying for such a rule, the established company owners could safeguard their control over the board. Although the direction of the hypothesized causal relationship remains unclear, the existence thereof seems plausible and should become clearer through a comparative and historical analysis of director removability without cause.

15 E.g. Mike Burkart et al., Large Shareholders, Monitoring, and the Value of the Firm, 112 Q. J. Fin. Econ. 693 (1997).

16 E.g. Rafael La Porta et al., Investor Protection and Corporate Valuation, 57 J. Fin. 1147 (2002). See however, with regard to the methodology: Sofie Cools, The Real Difference in Corporate Law Between the United States and Continental Europe: Distribution of Powers, 30 Del. J. CoRp. L. 697, 704-36 (2005).

17 Cools, supra note 16, at 745-50, 755-62; Sofie Cools, La répartition juridique des pouvoirs au sein des sociétés d'Europe continentale et des sociétés américaines, $106 \mathrm{REVUE}$ Pratique des Sociétés 149, 179-92 (2007). 


\section{Occurrence in Continental Europe}

This Part reveals how widespread the principle of at will removal of directors is on the European continent. The first section documents that it is most vigorously applied in one-tier boards, which occur mostly in jurisdictions of the French civil law tradition. In the second section, the principle is also shown to play an important role in two-tier boards, including those of the German tradition. The historical analysis in Part IV will moreover establish that this was even more so in one-tier boards in the German law tradition before it introduced the dual board structure.

\section{At Will Revocability in Single-Tier Boards}

Some of the strongest examples of at will revocability are found in French and Belgian corporate law. Both jurisdictions - which are highly similar in the field of corporate law - traditionally provided only for one-tier boards (conseil d'administration/raad van bestuur) and introduced the option of a two-tier board later. ${ }^{18}$ A single-tier board in a French or Belgian stock corporation (société anonyme/naamloze vennootschap) is appointed by the shareholders meeting. ${ }^{19}$ The corporate codes of both countries explicitly state that the meeting can also remove directors at any time. ${ }^{20}$ There is no maximum or minimum number of directors that can be removed simultaneously, no need to give a reason, to indemnify the dismissed director or to abide by a notice period. ${ }^{21}$ This is at will revocability to its full extent. It has been repeatedly labeled not just as a mandatory rule, but - even stronger - as a rule of public order. This implies that any clause in the charter or an agreement to which the corporation is a party, that states the contrary, or that would directly or indirectly impair the shareholders meeting to make use of its removal right, is null and void. ${ }^{22}$

18 See infra, Part II.2.

19 Art. L. 225-18, al. 1 French Commercial Code; art. 518 para. 2 Belgian Companies Code.

20 Art. L. 225-18, al. 2 French Commercial Code; art. 518 para. 3 Belgian Companies Code.

21 For France: Michel Germain, Les sociétés commerciales 459 (19th ed. 2009); Philippe Merle, Droit Commercial. Sociétés Commerciales 440 (14th ed. 2010). For Belgium: Jacques Malherbe et al., Droit des sociétés. Précis 540 (2004); Pierre Van Ommeslaghe, La cessation des fonctions des administrateurs, des gérants et des membres du comité de direction, in LES CONFLITS AU SEIN DES SOCIÉTÉs COMMERCIALES OU À FORME COMMERCiAle 109-10 (Editions du Jeune Barreau de Bruxelles ed., 2004). In France, the item of removal does not even have to appear on the meeting's agenda (art. L. 225-105 al. 3 French Commercial Code).

22 In addition, a void provision cannot be confirmed by the corporation when a dispute 
The consequences are extensive: the company's charter cannot increase the quorum or majority requirements for the shareholders meeting to remove directors, ${ }^{23}$ and even commitments by the company to pay golden parachutes to its directors are problematic. ${ }^{24}$

True, corporate law may not have the same goals as other fields of law. The field of labor law, in particular, has been gratefully used by directors to circumvent or alleviate some of the consequences of at will revocability. When a director can enter into a labor agreement with the company, he may derive substantial protection from that relationship. French and Belgian law have limited this possibility, among others by barring an employment agreement for any function that is not clearly different from the function of director. ${ }^{25} \mathrm{~A}$ second technique consists of entering into an agreement with one or more individual shareholders, in which the latter promises not to vote to dismiss the directors, or to personally commit to indemnification in case of removal. ${ }^{26}$

A somewhat similar picture exists in the Netherlands. A Dutch stock corporation (naamloze vennootschap) that is not subject to the "structure regime" 27 can have only a (managing) board of directors (raad van bestuur) and no supervisory board. These executive directors can be dismissed by those who appointed them, ${ }^{28}$ namely the shareholders meeting. ${ }^{29}$ The Dutch Civil Code explicitly states, in a mandatory way, ${ }^{30}$ that dismissal can be made at any time. ${ }^{31}$

arises if the infringed rule is of public order. This qualification is criticized by many scholars, who argue that the rule should be mandatory at most. Yves Guyon, Traité Des contrats. Les Sociétés. Aménagements statutaires et conventions entre associés 397-98 (5 $5^{\text {th }}$ ed. 2002) (France); Frank Hellemans, De Algemene VergaderING. EEN ONDERZOEK NAAR HAAR GRONDSLAGEN, HAAR BESTAANSREDEN EN DE GELDIGHEID VAN HAAR BESLUITEN 651 (2000) (Belgium); Koen Geens \& Hilde Laga, Overzicht van rechtspraak vennootschappen 1986-1991, TPR 1027-28 (1994) (Belgium).

23 Bernard Tilleman, Bestuur van vennootschappen 298-99 (2005) (Belgium); Pierre-Gilles Gourlay, Le Conseil d’Administration de la Société Anonyme. Organisation ET Fonctionnement 41 (1971) (France).

24 Merle, supra note 21, at 440-41 (France); Tilleman, supra note 23, at 300 (Belgium).

25 Tilleman, supra note 23, at 306 (Belgium). In addition, French law forbids a director already in function to become an employee and does not allow that more than one third of the directors are bound by an employment contract with the company (CozIAN ET AL., supra note 4, at 248-50; MerLe, supra note 21, at 448-51).

26 Malherbe et AL., supra note 21, at 543 (Belgium).

27 See infra, Part II.2.

28 Art. 2:134 para. 1 Dutch Civil Code.

29 Art. 2:132 para. 1 Dutch Civil Code.

30 Art. 2:25 Dutch Civil Code; C. Asser et al., Rechtspersonenrecht II. De naAmloze EN BESLOTEN VENNOOTSCHAP 533 (2009).

31 Art. 2:134 para. 1 Dutch Civil Code. This article also limits the possibility of increasing the majority and quorum requirements for dismissal of directors. 
There is no need to observe a notice period, to show a good cause or to dismiss a certain maximum or minimum number of directors at once. ${ }^{32}$ In other words, the rule of at will revocability is in full play in the corporate law provisions governing these "one-tier" corporations. However, Dutch law qualifies the relationship between a director and the company in which he serves as a hybrid, or combination, of a functional ("organ") and a contractual - mostly employment - relationship. Because they are indivisible, the termination of the former implies the termination of the latter. ${ }^{33}$ The director is therefore entitled to an indemnification if the notice period is not respected. ${ }^{34}$

Another qualification relates to the scope of at will revocability in corporate law. Not all jurisdictions on the European continent take at will revocability as far as described above. Italian corporate law, for example, recognizes the principle of at will revocability of board members, but with some exceptions. An Italian stock corporation (società per azioni) can be organized according to three models, ${ }^{35}$ one of which is a one-tier board structure. ${ }^{36}$ Under this structure, the company is governed by a board of directors with a supervisory committee installed within the board. As a rule, directors are appointed by a shareholders meeting ${ }^{37}$ and the directors then elect the members of the committee from among themselves. ${ }^{38}$ All or some of the directors can be revoked by the shareholders meeting at any time. ${ }^{39}$ The removal may take place even if there is no just ground, but in that instance an indemnification may be due..$^{40}$ Italy thus comes just one component short of full at will revocability for its one-tier boards.

A detailed and up-to-date analysis of all European jurisdictions falls outside the scope of this article. However, it should be noted that many of them, including Scandinavian states such as Denmark, Finland and Sweden, have been reported in extant legal doctrine to include some basic principle of at will revocability of directors. ${ }^{41}$ Similarly, corporate law in Luxembourg and Spain explicitly provide that members of a one-tier board in a stock corpo-

32 The law stipulates that "any director" can be removed "at any time" (id.). With regard to the absence of a notice period: J.B. HuIzInK, ReCHTSPERSOON, venNoOtschap EN ONDERNEMING 114 (2009).

33 Hoge Raad 15 april 2005, LJN AS2713, R.v.d.W. 2005, No. 55; Hoge Raad 15 april 2005, LJN AS2030, R.v.d.W. 2005, No. 57; Asser ET AL., supra note 30, at 518-21.

34 Asser ET AL., supra note 30, at 520.

35 Art. 2380 Italian Civil Code.

36 Art. 2409-sexiesdecies Italian Civil Code. For the two-tier structures, see infra Part II.2.

37 Art. 2383 al. 1, as referred to by art. 2409-noviesdecies Italian Civil Code.

38 Art. 2409-octiesdecies, al. 1 Italian Civil Code.

39 Artt. 2383 al. 3, 2409-noviesdecies Italian Civil Code.

$40 \mathrm{Id}$.

41 Wymeersch, supra note 6, at 1092 n.161. 
ration are not only appointed by the shareholders meeting, ${ }^{42}$ but also that they can be removed at any time. ${ }^{43}$

\section{A Watered-Down Version in Most Two-Tier Boards}

In two-tier boards, the appointment and removal of directors - especially of managing directors - is often no longer within the competence of the shareholders meeting. In addition, its say normally does not extend to supervisory board members appointed by another corporate constituency, such as the employee base, if any. This section demonstrates that, while these generalizations are true theoretically speaking, in practice the shareholders meeting often has considerable influence in the removal of members of both tiers of the board. The following paragraphs first deal with the most strict of two-tier board models, namely the German and the Dutch models, and then moves on to discuss removal in the optional and less stringent two-tier structures in several other European jurisdictions.

\section{(i) Germany, Austria and the Netherlands}

A text book case of a two-tier board is that found in the German and the-less well-known but strikingly similar - Austrian stock corporation (Aktiengesellschaft), which include a management board (Vorstand) and supervisory board (Aufsichtsrat). While this system increases director independence by reducing shareholder influence in the choice of members of the management board, the effect is often overstated. True, members of the management board are mandatorily and exclusively to be appointed by the supervisory board ${ }^{44}$ and can be dismissed only by the latter and only then for a good cause. ${ }^{45}$ Under certain

42 Art. 51 al. 3 Luxembourg Corporations Act. For Spain: Almudena Arpón de Mendívil, Spain, in Guide to European Company Laws 862 (Julian Maitland-Walker ed., $3^{\text {rd }}$ ed. 2008).

43 Artt. 50 \& 51 al. 4 Luxembourg Corporations Act. This provision is of public order: Pierre-Henri Conac, Les organes de la société anonyme (SA) en droit luxembourgeois, in Le nouveau droit luxembourgeois des sociétiés 53, 60 (André Prüm ed., 2008). For Spain: Arpón de Mendívil, supra note 42, at 863; Wymeersch, supra note 6, at 1092.

44 \$84(1), first sentence German Stock Corporation Act; $\mathbb{\$} 75(1)$ Austrian Stock Corporation Act.

45 \84(3) German Stock Corporation Act; $\$ 75(4)$ Austrian Stock Corporation Act. In Germany, a decision to dismiss a member of the management board can be taken by simple majority. However, if the company is subject to the codetermination regulations, a three-tiered procedure applies, starting off with a majority of at least two thirds in the first round and lowering the requirements in the next rounds (GERHARD WIRTH ET AL., 
conditions, the company may also agree to pay a termination fee. ${ }^{46}$ Moreover, when codetermination applies, a number of directors on the supervisory board are appointed and dismissed by the employees. ${ }^{47}$ However, several accompanying rules significantly mitigate the directors' independence.

To begin with, the shareholders meeting has a large degree of control over its representatives in the supervisory board, which always have the upper hand over employee representatives. ${ }^{48}$ Indeed, shareholder representatives in the supervisory board are elected by the general meeting with a simple majority ${ }^{49}$ and can be removed ad nutum by the shareholders meeting, ${ }^{50}$ with no requirement of good cause ${ }^{51}$ or right to indemnification. ${ }^{52}$ Admittedly, the default

Corporate Law in Germany 107 (2nd ed. 2010)). In Austria, the removal of management board members requires a "double majority", which means that both the board as a whole as well as shareholder representatives must vote in favor $(\$ 110$ (3) Labor Constitution Act; Susanne Kalss, Aktiengesellschaft, in Osterreichisches GesellschaftsRECHT para. 3/258) (Susanne Kalss et al., 2008).

46 Christoph H. Seibt, $\int 84$ Bestellung und Abberufung des Vorstands, in 1 Aktiengesetz Kommentar 948 (Karsten Schmidt \& Marcus Lutter eds., 2008) (Germany); Kalss, supra note 45, para 3/289 (Austria).

47 See the German Codetermination Act and the Austrian Labor Constitution Act. For an overview of the degree of worker involvement in case of German codetermination, see Christine Windbichler, Gesellschaftsrecht 369-70 (22 ${ }^{\text {nd }}$ ed. 2009); Wirth et al., supra note 45 , at $117-18$.

48 In Germany, employee representatives can take up to half of the supervisory board seats, but in that case the president, who is a shareholder representative, has a casting vote: WindBICHLER, supra note 47, at 374-75; WIRTH ET AL., supra note 45, at 123. In Austria, only one third of the supervisory board members are employee representatives $(\mathbb{1 1 0}(1)$ Labor Constitution Act). In addition, shareholders are protected by the double majority requirement (see supra, note 45).

49 \$101(1) German Stock Corporation Act; $\mathbb{8} 87(1)$ Austrian Stock Corporation Act. In Germany, the supervisory board has to make a non-binding proposal ( $\mathbb{S} 124(3), 101(1)$ German Stock Corporation Act). Both in German and Austrian publicly traded firms, the charter may empower the owners of specific restricted shares to appoint up to one third of shareholder representatives ( $\$ 101(2)$ German Stock Corporation Act; $\mathbb{\$} 88(1)$ Austrian Stock Corporation Act). In Austria, if at least three supervisory board members are elected in the same meeting, a minority of one third can insist on appointing a minority representative. ( $(87(4)$ Austrian Stock Corporation Act). In practice, the appointment procedure can be easily circumvented (Kalss, supra note 45, para. 3/483).

50 \$103(1) German Stock Corporation Act; $\mathbb{\$} 87(8)$ Austrian Stock Corporation Act. In Germany, supervisory board members can also be revoked by court upon request by the supervisory board or, under certain conditions, a minority of shareholders, if a good cause can be shown $(\$ 103(3)$ German Stock Corporation Act). In Austria, the supervisory board cannot request a removal, but a 10\% minority can $(\mathbb{8} 87(10)$ Austrian Stock Corporation Act).

51 Tim Drygala, $\int 103$ Abberufung der Aufsichtsratsmitglieder, in 1 AкTIEngesetz KomMENTAR, supra note 46, at 1139 (Germany); Kalss, supra note 45, para. 3/487 (Austria).

52 Drygala, supra note 51, at 1141 (Germany). 
majority requirement for removal is one of three fourths, ${ }^{53}$ but the articles can, and mostly do, set it at a simple majority. ${ }^{54}$ They cannot, however, impose substantive requirements for removal. ${ }^{55}$

In turn, the shareholders meeting, together with the supervisory board, has a larger degree of freedom in removing management board members than the good cause requirement would lead one to suspect. The reason is that if the shareholders meeting passes a vote of no confidence, this vote can be considered an important reason for removal. ${ }^{56}$ In that event, the supervisory board can, but is not obliged, to dismiss the managing director concerned. ${ }^{57}$ In practice, the supervisory board is in large part controlled by the shareholders meeting and will therefore likely meet the latter's wish. ${ }^{58}$ As a result, even though in theory the shareholders meeting does not dispose of the right of at will revocability as far as members of the management board are concerned, the practical outcome will often be functionally equivalent to a large extent. This effect is further strengthened in practice by the rule that director revocation is fully effective until proven that there was no adequate reason. ${ }^{59}$

One last qualification is in order. Again, corporate law does not provide the full picture. The internal relationship between directors and the stock corporation is not only an institutional (organ) relationship, but also a contractual one. ${ }^{60}$ Unless contractually agreed, ${ }^{61}$ the director's service agreement ${ }^{62}$ does

$53 \$ 103(1)$ German Stock Corporation Act; $\$ 87(8)$ Austrian Stock Corporation Act.

54 Id.; WIRTH ET AL., supra note 45, at 121 (Germany); Kalss, supra note 45, para. 3/487 n.123 (Austria).

55 Drygala, supra note 51, at 1140.

$56 \mathbb{8}$ 84(3) German Stock Corporation Act; $\mathbb{\$} 75(4)$ Austrian Stock Corporation Act. Although such resolution does not need a special justification, it may not be based on manifestly arbitrary grounds (id.; Seibt, supra note 46, at 968).

57 WirTh ET AL., supra note 45, at 106 (Germany); WindBichler, supra note 47, at 338 (Germany); Kalss, supra note 45, para. 3/306 (Austria).

58 See Windichler, supra note 47, at 381 (Germany); Peter Doralt, Die Unabbängigkeit des Vorstands nach österreichischem und deutschem Aktienrecht - Schein und Wirklichkeit, in Die Gestaltung der Organisationsdynamik (31) 47-48 (Werner H. Hoffmann ed., 2003) (Germany and Austria).

$59 \mathbb{8}$ 84(3) German Stock Corporation Act; $\mathbb{\$} 75(4)$ Austrian Stock Corporation Act. See Friedrich Kübler \& Heinz-Dieter Assmann, Gesellschaftsrecht 203 (6 $^{\text {th }}$ ed. 2006).

60 For members of the management board: KübleR \& Assmann, supra note 59, at 201 (Germany); Seibt, supra note 46, at 948 (Germany); Kalss, supra note 45, para. 3/278 (Austria). This is sometimes debated for members of the supervisory board: Tim Drygala, $\int 101$ Bestellung der Aufsichtsratsmitglieder, in 1 Aktiengesetz Kommentar, supra note 46, at 1123 (Germany); Kalss, supra note 45, para. 3/493 (Austria).

61 Seibt, supra note 46, at 973.

62 The agreement is qualified as a service contract, but not an employment agreement 
not automatically end upon his removal as director. Exceptionally, a sufficient ground may be present to terminate the contractual relationship without a notice period. ${ }^{63}$ If not - and this is not uncommon - the director will cease to hold office, but will continue to be paid until end of his or her term of office. ${ }^{64}$ Again we see that contract law can be used to mitigate the effects of revocation.

The second classic example of a board that is strongly separated into two tiers is the Dutch "large companies regime" or "structure regime" (structuurregime), which was introduced in 1971. This regime applies to companies that subject themselves voluntarily, as well as to large stock corporations (naamloze vennootschappen), i.e. companies that meet a number of criteria with regard to capital and number of employees and that have a works council.65 In the structure regime, a supervisory board (raad van commissarissen) is compulsory. ${ }^{66}$ The original version of the regime entailed an extreme deviation of the principle of ad nutum revocability. Members of the supervisory board were appointed through a system of "controlled co-optation" by the supervisory board itself, whereby shareholders' influence was reduced to a recommendation right and a limited right of objection. Put differently, they had "[relinquished] the essence of their power, namely the appointment and dismissal of supervisory board members" ${ }^{67}$

It should not come as a surprise that the exemptions offered by the Dutch Civil Code were eagerly used, ${ }^{68}$ and that the structure regime was considerably toned down in 2004. The shareholders meeting and the works council can still recommend supervisory board members to the supervisory board. ${ }^{69}$ The main difference is that, unless the charter stipulates differently, ${ }^{70}$ the latter then proposes candidates to the shareholders meeting, which decides on the actual

(Seibt, supra note 46, at 955 (Germany); Kalss, supra note 45, para. 3/280, 3/300 (Austria).)

63 KüBler \& Assmann, supra note 59, at 203 (Germany); Kalss, supra note 45, para. 3/279 (Austria).

64 Wirth ET AL., supra note 45, at 109 (Germany); Kalss, supra note 45, para. 3/279 (Austria). It should be noted that the maximum period of the service contract is five years ( $\$ 84(1)$ German Stock Corporation Act; $\$ 75(1)$ Austrian Stock Corporation Act).

65 Art. 2:153-154 Dutch Civil Code.

66 Art. 2:158 para. 1 Dutch Civil Code.

67 P. Van SchilfgaArde \& J. Winter, VAn de BV EN DE NV 415 (15 th ed. 2009) (own translation).

68 Art. 153 para. 3, 155, 155(a) Dutch Civil Code; Van Schilfgandde \& Winter, supra note 67 , at $415,434-39$.

69 Art. 2:158 para. 5 Dutch Civil Code. For one third of the members of the supervisory board, the candidates recommended by the works council must be proposed by the supervisory counsel unless it can invoke certain grounds listed in the statute (art. 2:158 para. 6 Dutch Civil Code).

70 Art. 2:158 para. 12 Dutch Civil Code. 
appointment. ${ }^{71}$ The 2004 amendments have thus improved shareholder say in the appointment of the supervisory board members. The same is true for their removal. When the shareholders meeting withdraws its confidence in the supervisory board - at will - the legal and mandatory consequence thereof is now the dismissal of the entire supervisory board. ${ }^{72}$ This is not so for individual supervisory board members. They cannot separately be removed against their will except by the enterprise chamber on the basis of specific (but broadly circumscribed) grounds listed in the statute. ${ }^{73}$ One important element is therefore missing to speak of full at will revocability, namely the ability to use the right of at will removal for whatever number of directors the shareholders meeting wishes. In addition, a Dutch court has seemingly indicated that the removal remains subject to a judicial test against the Dutch concept of reasonableness and fairness (redelijkheid en billijkheid). ${ }^{74}$ If confirmed in later jurisprudence, this would obviously put up another barrier to full at will removability.

To a certain degree, shareholders' influence filters through to the level of the management board. It is the supervisory board which appoints and dismisses members of the executive board,$^{75}$ with dismissal being possible at any time. ${ }^{76}$ Still, it cannot proceed to a dismissal without first having heard the shareholders meeting. ${ }^{77}$ While solely expressing its viewpoint, the shareholders meeting carries a big stick, thanks to its power to trigger dismissal of the entire supervisory board by withdrawing its confidence. Thus, even in the strictest regime meant to reduce shareholder influence, one can still discern the roots and effects of the rule of at will revocability. ${ }^{78}$

This goes much more for the second type of two-tier regime that exists in the Netherlands. Dutch companies that are not subject to the structure regime

71 Art. 2:158 para. 4 Dutch Civil Code. The shareholders meeting can reject the proposed candidate by an absolute majority of votes (art. 2:158 para. 9 Dutch Civil Code). At a first meeting of shareholders, this absolute majority must also represent at least one third of the outstanding capital. If the latter condition is not met, a second meeting can be held in which the condition no longer applies (id.).

72 Artt. 2:25, 2:161(a) Dutch Civil Code. Such a resolution must be made with an absolute majority that represents at least one third of the outstanding capital (id.).

73 Artt. 2:161 para. 2, 2:63(i) para. 2 Dutch Civil Code. A procedure before the enterprise chamber can, among others, be instituted by a representative of the shareholders meeting (art. 2:161 para. 2 Dutch Civil Code).

74 Enterprise Chamber 17 January 2007, LJN AZ6440, Ondernemingsrecht 2007, 157. See Huizink, supra note 32, at 129; Van SChilfgaArde \& Winter, supra note 67, at 429.

75 Art. 2:162 Dutch Civil Code. This cannot be restricted by a right of binding nomination by other entities (id.).

76 Art. 2:134 para. 1 Dutch Civil Code; Asser ET AL., supra note 30, at 730.

77 Id.

78 For the relationship with labor law, see supra Part II.1. 
can, on a voluntary basis, establish a supervisory board in addition to the management board. ${ }^{79}$ Both boards are then not only appointed by the shareholders assembly, ${ }^{80}$ but can also be dismissed by that assembly. ${ }^{81}$ Although not explicitly stated in the statute, it is generally assumed that this removal can be made at will. ${ }^{82}$ These rules on removal are mandatory. ${ }^{83}$ A company cannot deviate from them other than by voluntarily subjecting itself to the large companies regime. ${ }^{84}$ The law only allows for one exception: up to one third of the positions on a supervisory board can be elected and dismissed by others if the articles so provide. ${ }^{85}$ The more traditional Dutch two-tier regime thus more closely follows the general European principle.

\section{(ii) Some Other European Two-Tier Board Models}

As in Germany, Austria and the Netherlands, other jurisdictions with two-tier boards grant the shareholders meeting most influence at the level of the supervisory board. In France, an optional two-tier system with a managing board (directoire) and a supervisory board (conseil de surveillance) was introduced in $1966,{ }^{86}$ but has not become hugely popular. ${ }^{87}$ The members of the supervisory board are appointed by the shareholders meeting ${ }^{88}$ and can be revoked ad nutum by that meeting, even when that item was not put on the agenda of the meeting. ${ }^{89}$ Belgium more recently introduced an optional two-tier system, with a regular board of directors (conseil d'administration/raad van bestuur) and an executive committee (comité de direction/directiecomité). It differs from the French model in that the executive committee can be partially or entirely made up of members of the board of directors. ${ }^{90}$ For the directors, the

79 Art. 2:140 para. 1 Dutch Civil Code.

80 Artt. 2:132 para. 1, 2:142 para. 1 Dutch Civil Code. The articles of association can grant the right of binding nomination (of at least two candidates for each seat) to another corporate body than the shareholders meeting for the appointment of executive or supervisory directors (artt. 2:133 para. 1, 2:142 para. 2 Dutch Civil Code). The shareholders meeting can, however, deprive the nomination of its binding character (art. 2:133 para. 2 Dutch Civil Code).

81 Artt. 2:134 para. 1, 2:144 para. 1 Dutch Civil Code.

82 Asser et al., supra note 30, at 629; P. Sanders, Dutch Company Law 101 (1977); W.J. Slagter, Ondernemingsrecht 340 ( $8^{\text {th }}$ ed. 2005).

83 Art. 2:25 Dutch Civil Code.

84 Van SchilfgaArde \& Winter, supra note 67, at 209.

85 Artt. 2:143, 2:144 para. 1 Dutch Civil Code.

86 Artt. 118-150 Act No. 66-537 of 24 July 1966, J.O. 26 July 1966, 6402.

87 Cozian ET AL., supra note 4, at 301; Germain, supra note 21, at 263 (2009).

88 Art. L. 225-75 French Commercial Code.

89 Art. 225-75 al. 2 French Commercial Code.

90 Art. 524bis Belgian Companies Code. In contrast, a member of a French supervisory 
same rules apply as under the one-tier system. This implies election in and removal from their function as a director by the shareholders meeting, with a mandatory rule that be possible at will. ${ }^{91}$ Similarly, the Luxembourg two-tier board is optional, ${ }^{92}$ with the supervisory board (conseil de surveillance) being subject to the same at will removal right as a one-tier board. ${ }^{93}$ Finally, the Italian elective dualistic system ${ }^{94}$ with a management board (consiglio di gestione) and a supervisory board (consiglio di sorveglianza) ${ }^{95}$ fits in this general scheme, with one qualification. Members of the supervisory board are in principle appointed by the shareholders meeting ${ }^{96}$ and can be removed at will by the shareholders meeting, ${ }^{97}$ but the company must indemnify dismissed directors for damages that ensue from their removal. ${ }^{98}$

Even at the level of the management board, French law remains close to the standard of ad nutum removability by the shareholders meeting. Although the managing board is appointed by the supervisory board, ${ }^{99}$ it is to be removed by the shareholders meeting if the articles of association do not grant this power to the supervisory board. ${ }^{100}$ Such removal can, once again, be made at any time. ${ }^{101}$ Admittedly, the removal can give rise to an indemnification duty if no just cause is present, ${ }^{102}$ but even a divergence of opinions on how to run the company, or a decision to return to a one-tier board is considered a just

board cannot be a member of the managing board (art. L. 225-74 French Commercial Code).

91 Jean-Marie Nelissen Grade, Het nieuwe directiecomité, in Nieuw venNootschapsRECHT 2002. Wet CORPorate governance 106, 125 (Jan Ronse Instituut ed., 2003).

92 Art. 60bis-1 Luxembourg Companies Act.

93 Art. 60bis-4 Luxembourg Companies Act. There is some debate as to whether at will removal is mandatory in a two-tier board (Conac, supra note 43).

94 Art. 2409-octies Italian Civil Code.

95 Art. 2409 Italian Civil Code. Supervisory board members may not occupy a position in the management board (art. 2409-duodecies al. 10 Italian Civil Code; see Federico Pernazza, Italy, in International Encyclopedia of Laws 121 (Roger Blanpain ed., 2009).

96 Art. 2409-duodecies al. 2 Italian Civil Code. See Pernazza, supra note 95, at 120-21.

97 Art. 2409-duodecies al. 5 Italian Civil Code.

98 Id.

99 Art. L. 225-59 al. 1 French Commercial Code.

100 Art. L. 225-61 al. 1 French Commercial Code; CozIAn ET AL., supra note 4, at 302; Germain, supra note 21, at 497. Before the Act of 15 May 2001, the shareholders meeting could revoke managing directors only upon proposal by supervisory board and an indemnification was due in the absence of a just cause for removal (old art. L. 225-61 al. 1 French Commercial Code; Jean-Luc Aubert, La révocation des organes d'administration des sociétés commerciales, Rev. TRIm. Dr. comm. 981 (1968); MerLe, supra note 21, at 540).

101 Art. L. 225-61 al. 1 French Commercial Code.

102 Art. L. 225-61 al. 1 French Commercial Code. 
cause. ${ }^{103}$ For better protection a managing director has to look outside the area of corporate law, as he can in most cases enter into an employment agreement. ${ }^{104}$

In contrast, shareholder say in removing managing directors is only indirect in Belgium, Luxembourg and Italy. In Belgium, executive committee members are in principle removable at will by the board of directors. ${ }^{105}$ Stockholders can thus exercise their influence only through the board of directors, which is removable at the will of the shareholders meeting. ${ }^{106}$ However, both the rule of at will removal of executive committee members and the competence of the board of directors in this regard are merely default rules. ${ }^{107}$ The shareholders meeting can thus decide to amend the charter to increase or decrease its influence in the dismissal of executive committee members. Similarly, the managing directors in a Luxembourg two-tier board are appointed by the supervisory board, ${ }^{108}$ except if articles of association stipulate that this is a power of the shareholders meeting. ${ }^{109}$ Removal then also happens through the supervisory board and, if the articles of association so stipulate, the shareholders meeting. ${ }^{110}$

In the Italian dual system as well, members of the management board are appointed by the supervisory board ${ }^{111}$ and can be removed at will by the supervisory board. ${ }^{112}$ The rule of at will removal is in play, again with the qualification that damage caused by removal without a good cause is to be indemnified. ${ }^{13}$ At will removal, with a qualification on the condition of no payment obligations, thus carries over to the level of the management via a controlled supervisory board. Again, at will removal thus plays a larger role than it would appear at first sight. Italy, however, also has a third, more traditional board structure that is different from the traditional two-tier boards and in which at will removal is strictly limited to one tier of the board. In this system, the company is governed by a board of directors and an independent board of auditors (collegio sindacale). The directors are in principle appointed ${ }^{114}$ and removable at will by the shareholders meeting. If no just cause

103 Cozian ET AL., supra note 4, at 302; Germain, supra note 21, at 498.

104 Germain, supra note 21, at 498; MerLe, supra note 21, at 542.

105 Nelissen Grade, supra note 91, at 124; Van Ommeslaghe, supra note 21, at 116.

106 See supra, text accompanying note 91.

107 Nelissen Grade, supra note 91, at 124; Van Ommeslaghe, supra note 21, at 116.

108 Art. 60 bis-3 al. 1 Luxembourg Companies Act.

109 Art. 60bis-3 al. 2 Luxembourg Companies Act.

110 Art. 60bis-5 Luxembourg Companies Act.

111 Artt. 2409-nonies al. 3, 2409-terdecies Italian Civil Code.

112 Art. 2409-nonies al. 5 \& 2409-terdecies Italian Civil Code.

113 Art. 2409-nonies al. 5 Italian Civil Code.

114 Art. 2383 al. 1 Italian Civil Code. See Pernazza, supra note 95, at 104-05. 
can be shown, the removed director is entitled to an indemnification, ${ }^{115}$ covering the forfeited fees and ancillary benefits. ${ }^{116}$ The shareholders meeting also appoints the board of auditors, ${ }^{117}$ but it can proceed to removal only on just grounds and with approval of the court. ${ }^{118}$

\section{European Union Law on the Sidelines}

Part II uncovered a remarkable commonality among the corporate laws of several European jurisdictions with regard to director revocation. The following paragraphs show that the European Union has not played any role in creating this commonality. It has never imposed any provision relating to director removal on its member states. Furthermore, the rule of at will revocability also traditionally existed in a civil law jurisdiction that is not a member of the European Union, namely Switzerland. ${ }^{119}$

\section{Absence of Regulation by European Union}

On two occasions, the European Union came close to regulating the appointment and removal of directors. Twice, it failed to do so because of insurmountable political opposition on the choice between one-tier and two-tier boards, and especially on the question of employee involvement.

One occasion was the draft Fifth Company Law Directive, the original proposal for which dates from $1972 .{ }^{120}$ On the German model, it contemplated the compulsory establishment of a two-tier system of boards of directors, coupled either with employee representation on a supervisory board elected by the shareholders meeting ${ }^{121}$ or with a right of opposition for shareholders and employees against appointment in case of a self-co-opting supervisory board. ${ }^{122}$ The management board would be appointed and removed by the

115 Art. 2383 al. 3 Italian Civil Code.

116 Pernazza, supra note 95, at 107.

117 Art. 2400 al. 1 Italian Civil Code.

118 Art. 2400 al. 2 Italian Civil Code.

119 The case of the United Kingdom will be dealt with in Part V.

120 Proposal for a Fifth Directive on the Coordination of Safeguards Which for the Protection of the Interests of Members and Outsiders, are Required by Member States of Companies Within the Meaning of Article 59, Second Paragraph, with Respect to Company Structure and to the Power and Responsibilities of Company Boards, 1972 O.J. (C 131) 49 [hereinafter Proposed Fifth Directive].

121 Id. art. 4(2).

$122 I d$. art. 4(3). 
supervisory board. ${ }^{123}$ The latter would, in turn, be appointed by the shareholders meeting, ${ }^{124}$ with obvious exceptions for worker representatives ${ }^{125}$ and for supervisory boards chosen by co-optation. ${ }^{126}$ Aside from these exceptions, the proposal followed the tradition of the Old Continent with regard to at will removal of directors. If adopted, it would have rendered supervisory board members subject to removal at any time by those who appointed them. ${ }^{127} \mathrm{~A}$ single exception was drawn for members of a supervisory board elected by cooptation, who could be recalled only on proper grounds and with judicial intervention. ${ }^{128}$

Opposition against the proposed Directive led the European Parliament to amend it in 1982 and the Commission to issue a new proposal in $1983 .{ }^{129}$ They rendered the dualistic system optional and also allowed for a monistic board consisting of both executive and non-executive directors. ${ }^{130}$ The new draft maintained the earlier proposed provisions on removing members of supervisory and management board for the dual board system. ${ }^{131}$ In addition, it explicitly provided for at will revocability of the members of a single-tier board. ${ }^{132}$ At will revocability thus played an important role in the European framework. These provisions were not touched in the further history of the

123 Id. artt. 2 resp. 13(1)). The Economic and Social Committee advised that removal should be possible exclusively on the basis of important reasons (Advice of the Economic and Social Committee, 1974 O.J. (C 109) 9, 13).

124 Artt. 4(2) al. 1, 4(4) Proposed Fifth Directive.

125 Art. 4(2) al. 2 Proposed Fifth Directive.

126 Art. 4(3) Proposed Fifth Directive.

127 Art. 13(2) Proposed Fifth Directive.

128 Artt. 13(2), 4(3) Proposed Fifth Directive.

129 Resolution Embodying the Opinion of the European Parliament on the Proposal from the Commission of the European Communities to the Council for a Fifth Directive to Coordinate the Safeguards Which, for the Protection of the Interests of Members and Others, are Required by Member States of Companies Within the Meaning of the Second Paragraph of Article 58 of the EEC Treaty, as Regards the Structure of Sociétés Anonymes and the Power and Obligations of Their Organs, 1982 O.J. (C 149) 20 [hereinafter EP Opinion]; Amended Proposal for a Fifth Council Directive Founded on Article 54 (3) (G) of the Treaty Concerning the Structure of Public Limited Companies and the Powers and Obligations of Their Organs, 1983 O.J. (C 240) 2 [hereinafter First Amended Proposal].

130 Artt. 21bis-21undecies EP Opinion; artt. 21a-21u First Amended Proposal.

131 Art. 13 EP Opinion; art. 13 First Amended Proposal.

132 The Parliament's amendments did not distinguish between removal of executive and of non-executive directors (art. 21decies EP Opinion). The amended proposal of 1983 was different in that it provided that executive members could be removed by non-executive and that non-executive members could be removed at any time by those who appointed them (art. 21(t) First Amended Proposal). 
draft Fifth Directive, in the second amended proposal of $1991,{ }^{133}$ or, despite opposition from the Economic and Social Committee, ${ }^{134}$ in the third amended proposal of the same year. ${ }^{135}$ Still, they did not become part of the European acquis communautaire. The Draft Fifth Directive died a slow death and was eventually withdrawn as an obsolete proposal in 2004. ${ }^{136}$

Another attempt to lay down state-of-the-art rules on the governance of public companies was undertaken on the occasion of the introduction of a European Company, or "Societas Europaea". This initiative had an even longer history than the failed Fifth Directive, ${ }^{137}$ but it was more successful, as it led to the enactment of Regulation 2157/2001 (hereafter the "European Company Regulation"). ${ }^{138}$ However, the issue of director appointment and removal was largely sidestepped, as the Regulation does not make, or require the member states to make, a choice between a one-tier or a two-tier system. That decision is to be made in the statutes of each individual European Company and thus by its shareholders meeting. ${ }^{139}$ If the shareholders meeting opts for a one-tier system, it will appoint the single administrative organ itself, ${ }^{140}$ similar

133 To the contrary, the second amended proposal implicitly supported at will revocability by providing that neither national law nor a company's charter could require more than an absolute majority for the appointment or removal of directors: art. 36(3) Second Amendment to the Proposal for a Fifth Council Directive Based on Article 54 of the EEC Treaty Concerning the Structure of Public Limited Companies and the Powers and Obligations of Their Organs, 1991 O.J. (C 7 ) 4.

134 Opinion of the Economic and Social Committee on the Second Amendment to the proposal for a Fifth Council Directive based on Article 54 of the EEC Treaty concerning the structure of public-limited companies and the powers and obligations of their organs, 1991 O.J. (C 269) 48, 51.

135 Third Amendment to the Proposal for a Fifth Council Directive Based on Article 54 of the EEC Treaty Concerning the Structure of Public Limited Companies and the Powers and Obligations of Their Organs, 1991 O.J. (C 321) 9.

136 Withdrawal of obsolete Commission proposals, 2004 O.J. (C 5) 2-33.

137 Proposition de Règlement (CEE) du Conseil portant statut de la société anonyme européenne, 1970 J.O. (C 124) 1. For the English version, see Bull. EC Supp. No. 8 (1970).

138 Council Regulation 2157/2001 on the Statute for a European Company, 2001 O.J. (L 294) 1 [hereinafter European Company Regulation].

139 Art. 38 European Company Regulation.

140 Art. 43(3) European Company Regulation. In the European Company, up to half of the members of the supervisory or administrative organ may be appointed by employees. Council Directive 2001/86 supplementing the Statute for a European company with regard to the involvement of employees, 2001 O.J. (L 294) 22. If half of the members are appointed by employees, only a member appointed by the shareholders meeting may be elected chairman of the administrative organ (art. 45 European Company Regulation) or, in the case of a two-tier board, the supervisory organ (art. 42 European Company Regulation). This is an important specification, as the chairman has casting vote in the event of a tie (art. 50(2) European Company Regulation). 
to the above described situation for Belgian and French public companies with a single-tier structure. ${ }^{141}$ In case of a European Company with a two-tiered board, the shareholders meeting appoints only the supervisory organ, ${ }^{142}$ which in turn appoints and recalls the management organ, ${ }^{143}$ as in a German public company. ${ }^{144}$ A member state may, however, deviate from the latter rule and require or permit the statutes to provide that the member(s) of the management organ be appointed and removed by the shareholders meeting under the same conditions as for public limited-liability companies that have registered offices within its territory, ${ }^{145}$ such as, for instance, in a Dutch public company with a two-tier board. ${ }^{146}$

The European Company Regulation did not enter into further detail on director revocation and refrained from specifying that the shareholders meeting be able to revoke the members of a single-tier board or of a supervisory board. The attribution of this competence is left to the statutes of the European Company and national law. ${ }^{147}$ The one time that director removal was successfully broached at the EU level, the European legislator did not address the question of whether such removal should be possible at will.

\section{The Case of Switzerland}

The previous paragraphs have shown that the norm of at will removal of directors by the shareholders meeting does not ensue from European law. Instead, it seems more closely connected to the European civil law tradition as such. Switzerland is a natural test case for this statement and provides anecdotal evidence supporting a link with civil law.

A Swiss public corporation (Aktiengesellschaft/société anonyme) is organized according to a one-tier system, in which the board of directors (Verwaltungs$\mathrm{rat} /$ conseil d'administration) manages the business of the company. ${ }^{148}$ It is

141 See supra, Part II.1.

142 Art. 40(2) European Company Regulation.

143 Art. 39(2) al. 1 European Company Regulation.

144 See supra, Part II.2(i).

145 Art. 39(2) al. 2 European Company Regulation.

146 See supra, Part II.2(i).

147 See art. 52 al. 2 (referring to the European Company's statutes and national law for the non-regulated powers of the shareholders meeting) and art. 9 European Company Regulation (setting out the hierarchical order of applicable provisions).

148 Art. 716 para. 2 Swiss Code of Obligations (as far as it has not delegated certain tasks to the management). 
appointed by the shareholders meeting at its free discretion. ${ }^{149}$ The latter can also revoke the directors at any time, ${ }^{150}$ without any need for justification. ${ }^{151}$ This right of removal at will is mandatory. ${ }^{152}$ The articles of association can therefore not subject the revocation to the existence of a good cause. ${ }^{153}$

Although the principle of at will revocation is considered a vital element of Swiss corporate law, ${ }^{154}$ it is subject to two qualifications. First, to some extent the company's articles of association may require a larger majority than the default rule of a simple majority. ${ }^{155}$ However, a higher threshold may not render dismissal impossible in the concrete case, ${ }^{156}$ a condition that is believed not to be satisfied for requirements of more than three-quarter majorities. ${ }^{157}$ Second, the Swiss code stipulates that removed directors may be entitled to an indemnity, ${ }^{158}$ but that is the case only if the director also has a labor agreement with the company, and only then if removal is made without a just cause. ${ }^{159}$ As in France and Belgium, a director can have a labor agreement with the company only for another function in the company than that of director. ${ }^{160}$ If the director does not have a labor agreement, then indemnification is not due if the removal was not untimely. ${ }^{161}$ Within the strict area of corporate law, however, Switzerland fits the general scheme, because it showcases full at will revocability.

\section{The Origins of the Mandatory Rule of At Will Revocability}

The previous Parts have revealed that ad nutum revocability seems tied to the civil law tradition but not to the European Union. This is not a mere coincidence. Part IV shows that mandatory at will revocability dates back far earlier

149 Art. 698 para. 2 No. 2 Swiss Code of Obligations; Peter Böckli, Schweizer AktienRECHT 1557 (4th ed. 2009).

150 Art. 698 para. 2 No. 6, 705 para. 1 Swiss Code of Obligations.

151 Heinrich Honsell et al., Basler Kommentar. Obligationenerecht II. Art. 5901186 OR 964 (3rd ed. 2008).

152 Marc Bauen et al., La société anonyme suisse 174 (2007); Peter Forstmoser et AL., Schweizerisches Aktienrecht 284 (1996); Honsell Et Al., supra note 151, at 964.

153 BöcKLI, supra note 149, at 1565; Honsell ET AL., supra note 151, at 964.

154 BöcKLI, supra note 149, at 1564.

155 Id. at 1565; Honsell ET AL., supra note 151, at 965.

156 Id.

157 Honsell ET AL., supra note 151, at 965.

158 Art. 705 para. 2 Swiss Code of Obligations.

159 Honsell ET AL. supra note 151, at 966.

160 BöcKLI, supra note 149, at 1634.

161 Id. at 1635; Honsell ET AL., supra note 151, at 966. 
than the European Union. It first developed in France (Section 1) and rapidly spread over continental Europe (Section 2).

\section{The Development of At Will Revocability in France}

Historians trace the origins of the stock corporation back to the seventeenth century chartered companies for overseas expeditions, the medieval commen$d a$, the late medieval Italian banks, Roman publican companies and companies of heirs or even to earlier civilizations. ${ }^{162}$ Limited liability came to its full development in the East India companies which first emerged in England and the Netherlands at the dawn of the seventeenth century, and later also in France and the German territories. ${ }^{163}$ Their establishment always necessitated governmental approval, and the applicable rules were determined on a case-by-case basis. ${ }^{164}$ The directors were generally not revocable and were often even appointed for life - or for the duration of the company. ${ }^{165}$

The first attempt to set out general rules applicable to all companies was made in France under King Louis XIV and his Minister for Economic Affairs, JeanBaptiste Colbert. They commissioned businessman Jacques Savary to codify

162 Louis FredericQ, Traité de Droit Commercial Belge 419 (1950); Ernest Frignet, Histoire de l'association commerciale 45-74 (1868); Jean Hilaire, Introduction Historique au Droit Commercial 167-70 (1986); Malherbe et al., supra note 21, at 258; Jan Ronse, Algemeen Deel van het Vennootschapsrecht 10-11 (3rd ed. 1975); Troplong, Commentaire du Contrat de Société en Matière Civile et Commerciale 259 (1843); Guido A. Ferrarini, Origins of Limited Liability Companies and Company Law Modernisation in Italy: A Historical Outline, in VOC 1602-2002: 400 Years of Company Law 190 (Ella Gepken-Jager et al. eds., 2005).

163 Pierre-Henri Conac, The French and Dutch East India Companies in Comparative Legal Perspective, in VOC 1602-2002, supra note 162, at 133 (France); Ella GepkenJager, The Dutch East India Company, in VOC 1602-2002, supra note 162, at 41-81 (Netherlands); Ron Harris, The English East India Company and the History of Company Law, in VOC 1602-2002, supra note 162, at 219, 219-20 (England); Erik Kießling, Das preußische Eisenbahngesetz von 1838, in 1 AкTIENRecht im Wandel. Entwicklung des Aktienrechts 126, 134 (Walter Bayer \& Mathias Habersack eds., 2007) (Prussia).

164 Conac, supra note 163, at 136, 148 (France); Albrecht Cordes \& Katharaina Jahntz, Aktiengesellschaften vor 1807?, in 1 AKTIENRECHT IM WANDEL, supra note 163, at 15 (general); Gepken-Jager, supra note 163, at 44-45 (Netherlands); Harris, supra note 163, at 219-20 (England).

165 Conac, supra note 163, at 142-43 (France: limited term in 1664, but for life in 1723); Cordes \& Jahntz, supra note 164, at 21 (general); Gepken-Jager, supra note 163, at 5455 (Netherlands: governors first appointed for life, but as of 1623 only for three-year terms; directors appointed until next Chamber meeting). 
the unwritten customary commercial laws, which in 1673 resulted in a decree now commonly referred to as the Decree of Colbert, the Ordonnance de commerce, the Code Marchand or the Code Savary. ${ }^{166}$ The few companyrelated provisions dealt only with partnership forms, ${ }^{167}$ in which all associates or the managing associates had the power to run the company. ${ }^{168}$

Gradually, organizations were created in France that featured some traits characteristic of the stock corporation, such as transferable shares, centralized management and limited liability. ${ }^{169}$ Their charters commonly allotted the power to appoint and revoke directors to the meeting of shareholders. ${ }^{170}$ The charters of these germinal stock corporations served as a source of inspiration for the French Code de Commerce, ${ }^{171}$ enacted in 1807 during Napoleon's reign. This codification reflected existing law and practice rather than attempting to innovate. ${ }^{172}$ In addition to the forms regulated by the Decree of Colbert, the Code de Commerce now explicitly covered the stock corporation (société anonyme). ${ }^{173}$ Government approval was no longer required for starting up the former, but it remained a condition for establishment of the latter. ${ }^{174}$ The stock corporation distinguished itself from the old company forms in that its governance could be entrusted to non-shareholders. ${ }^{175}$ Directors ${ }^{176}$ were

166 Philippe Bornier, Ordonnance de Louis XIV sur le Commerce 55-75 (1767).

167 Article 1 of the Decree refers to the société générale (or société en nom collectif) and the société en commandite. Legal practice had also developed a third form called the société anonyme. Contrary to its current meaning, the société anonyme was anything but a stock corporation, and instead referred to a sleeping partnership. BORNIER, supra note 166, at 57-58; 2 Jacques Savary, Le Parfait Négociant 20-25 (2nd ed. 1679).

168 Henri Lévy-Bruhl, Histoire Juridique des Sociétés de Commerce en France AuX XVII e ET XVIII Siècles 159, 191 (1938).

169 Hilaire, supra note 162, at 202-06; Lévy-Bruhl, supra note 168, at 30, 42-53.

170 LÉvY-BRUHL, supra note 168, at 196. It should be noted, however, that the composition of the meeting of shareholders and that of the meeting of directors were often overlapping entirely. $I d$. at 204.

171 Troplong, supra note 162, at 173.

172 Jean-Louis Halpérin, Histoire des droits en Europe de 1750 à nos Jours 64 (2004); Andreas Deutsch, Die Aktiengesellschaft im Code de Commerce von 1807 und ibre Vobildfunction für die Entwicklung in Deutschland, in 1 AкTIENRECHT IM WANDEL, supra note 163 , at $48-49$.

173 Art. 29-37 Code de Commerce of 1807. As of then, the term société anonyme was reserved for the stock corporation and no longer referred to sleeping partnerships (see supra note 167). The Code de Commerce also allowed the sleeping partnership, as of then called association en participation. Artt. 47-50 Code de Commerce of 1807.

174 Art. 37 Code de Commerce of 1807.

175 Art. 31 Code de Commerce of 1807; Deutsch, supra note 172, at 65 (Fremdorganschaft).

176 It should be noted that the term "directors" in the beginning of the nineteenth century 
considered agents for the corporation, ${ }^{177}$ a classification which had appeared earlier in the French Code Civil of $1804 .{ }^{178}$ Pursuant to the Code Civil, an agent's mandate could be revoked at the principal's discretion. ${ }^{179}$ In accordance with this principle, the Code de Commerce stipulated that the société anonyme "is governed by temporary, revocable agents". ${ }^{180}$ On the basis of this absolute wording and the specific character of the société anonyme - with numerous investors for whom not the person of the director(s) but the company's project is of overriding importance - legal scholars immediately construed this rule to be essential to the stock corporation. ${ }^{181}$ Unlike in agency law and other corporate forms, the rule of at will removability was therefore considered mandatory in the société anonyme. ${ }^{182}$

\section{The Proliferation of At Will Revocability in Continental Europe}

The impact of the Code de Commerce cannot be overestimated. It was directly applicable in Napoleon's empire and dependent territories, and served as a model far beyond its borders. ${ }^{183}$ The following paragraphs illustrate that, together with the Code de Commerce, the rule of at will revocability of board members became widespread on the European continent and largely remained in force until today.

First of all, as one can deduce from the previous Parts, the provision on at will

also included top management (ANne LeFèbvre-TeIllard, La SociÉTÉ ANONYME AU XIXe SIÈCLE 259-62 (1985)).

177 Artt. 31-32 Code de Commerce of 1807.

178 The Napoleonic Codes distinguished between civil and commercial corporate law (art. 1873 Civil Code of 1804; art. 18 Code de Commerce of 1807). In civil corporate law, directors were revocable at will unless they had been appointed in the incorporation deed. Art. 1856 al. 2 Code Civil of 1804 : "Ce pouvoir ne peut être révoqué sans cause légitime, tant que la société dure; mais s'il n'a été donné que par acte postérieur au contrat de société, il est révocable comme un simple mandat." (emphasis added) Civil corporate law did not apply to companies with commercial activities and will be left out of consideration in the present study.

179 Art. 2004 Code Civil of 1804.

180 Art. 31 Code de Commerce of 1807: "Elle est administrée par des mandataires à temps, révocables, associés ou non associés, salariés ou gratuits."

181 M. Delangle, Des sociétés commerciales 170-71 (1844); M. Delangle, Commentaire sur les Sociétés Commerciales, in Troplong, supra note 162, at 547-48.

182 Id.; T. Campenon, Le Code de Commerce et les Lois Commerciales. CommenTAIRE Usuel 12 (1865). The classification as mandatory law deviates from agency law, where at will revocability is merely a default rule. Delangle, in Troplong, supra note 181 , at 548.

1831 Pierre Arminjon et al., Traité de droit comparé 131-79 (1950); Halpérin, supra note 172, at 64-66. 
revocability remained applicable in France. It was repeated in a ministerial instruction of 22 October $1817 .{ }^{184}$ In accordance with this instruction, the government systematically rejected charter provisions that would limit the effects of at will revocability. ${ }^{185}$ The provision that directors were revocable was repeated in the Act of 24 July 1867, ${ }^{186}$ which abolished the requirement of government approval for the constitution of a stock corporation ${ }^{187}$ and which served as a basis for current French corporate law. ${ }^{188}$ The provision was still interpreted as imposing at will revocability and continued to be counted as an essential and mandatory part of the law for stock corporations. ${ }^{189}$ Not surprisingly, the next major corporate law revision in 1966 resulted in an explicit affirmation of at will revocability: at any time, the shareholders meeting could remove members of the pre-existing one-tier board, ${ }^{190}$ as well as the members of both parts of the newly introduced and optional two-tier board. ${ }^{191}$ These provisions survived and were codified in the new commercial code of 18 September 2000. ${ }^{192}$

Napoleon's Code de Commerce was equally applicable in the Southern Netherlands, as they had been annexed to the French republic in 1794. Upon the Northern and Southern Netherlands' independence and formation of the Dutch Kingdom in 1815, steps were taken to elaborate a new commercial code. ${ }^{193}$ Before the Dutch commercial code entered into effect, however, Belgium separated itself from the Northern Netherlands in 1830. The Code de Commerce, which had continued to be in force in the meantime, was maintained upon independence with the intention to subject it to revision. ${ }^{194}$ The company law provisions were not revised until the Act of 18 May $1873 .{ }^{195}$ The Act drew inspiration from the recent French corporate law amendments and abolished the required authorization for the incorporation of new stock cor-

1843 Ministère de l'intérieur, Circulaires, instructions, et autres actes 266, 270 (2nd ed. 1823) ("les actes sociaux ne peuvent réserver à aucun individu [.. .] aucun droit à la gestion perpétuelle ou irrévocable").

185 Charles E. Freedeman, Joint-Stock Enterprise in France, 1807-1867: From Privileged Company to Modern Corporation 43 (1979).

186 Art. 22 Act of 24 July 1867.

187 Id. art. 21.

188 Germain, supra note 21, at 259; Pierre Van Ommeslaghe, Le Régime des Sociétés par Actions et leur Administration en Droit Comparé 80 (1960).

189 H.-F. Rivière, COMMENTAIRE DE LA LOI DU 24 JUILLET 1867 SUR LES SOCIÉTÉs 226-27 (1868).

190 Art. 90 al. 2 Act No. 66-537 of 24 July 1966, J.O. 26 July 1966, 6402.

191 Id. artt. 121, 134.

192 See supra, Part II.2(ii).

193 Asser ET AL., supra note 30, at 3-4.

194 Art. 139 Belgian Constitution of 1831.

195 P. Namur, Le Code de Commerce Belge Revisé 13-15 (1884). 
porations. ${ }^{196}$ It also explicitly adopted the at will revocability of directors, stipulating that "they are always revocable by the general meeting [of shareholders]". ${ }^{197}$ After the French example, this provision was considered mandatory law and even "of public order" 198 and has therefore survived further company law revisions. ${ }^{199}$ The current Belgian Companies Code, in fact, contains the exact same provision on director revocability as the Act of 1873.200

The French Code de Commerce of 1807 was also imposed in the Northern Netherlands during their occupation in $1811 .{ }^{201}$ After their liberation a few years later, the Dutch started preparing their own commercial code (Wetboek van Koophandel) which, after some delay due to negotiations with Southern Netherlands and their subsequent secession, was finally adopted and in force in 1838. ${ }^{202}$ The Dutch commercial code reiterated many of the Code de Commerce's provisions on stock corporations, ${ }^{203}$ and in the same line of thought provided that directors could not be irrevocably appointed. ${ }^{204}$ As indicated above, it was only in 1971 that the major exception of the structure regime was introduced. ${ }^{205}$

The influence of the Napoleonic codification also reached German corporate law, starting off with its application in those parts that were annexed to or depended on France. ${ }^{206}$ After the breakdown of the French empire, several

196 See artt. 4, 30 Act of 18 May 1873.

197 Art. 45 al. 3 Act of 18 May 1873 (own translation). See id. art. 43.

198 J. Guillery, Commentaire Législatif de la Loi du 18 Mai 1873 sur les Sociétés Commerciales en Belgique 122 (1878); Charles Resteau, Traité des Sociétés Anonymes 69-70 (1933).

199 See Ministerial Instruction of 20 February 1841 Regarding the Applications for Authorization for the Formation of New Stock Corporations, $\$ 10$ al. 2: "Il est stipule que les admistrateurs [...] sont nommés et toujours révocables par l'assemblée générale." In the twentieth century, a proposal to modify company law included substantial toning down of the rule of at will revocability, but it was never adopted (Artt. 90, 94 para. 2, 99 para. 1 Bill, Doc. parl., Ch. Repr., 1979-80, No. 387).

200 Art. 518 para. 3 Belgian Companies Code.

201 Asser ET AL., supra note 30, at 3; Deutsch, supra note 172, at 89; R.J.Q. Klomp, 'Deze ijdele praal'. Het handelsrecht in Nederland na de codificatie, in TwEEHONDERD JAAR wetboek van KoOpHANDEL - Bicentenaire DU CODE DE COMMERCE 105, 110-11 (G. Martyn \& D. Heirbaut eds., 2009).

202 Deutsch, supra note 172, at 89-90; AsSER ET AL., supra note 30, at 3-4.

203 Deutsch, supra note 172, at 90; Klomp, supra note 201, at 112-18; Norbert Reich, Die Entwicklung des deutschen Aktienrechtes im neunzehnten Jabrbundert, in 2 Ius Cомmune. Veröffentlichungen des Max-Planck-Instituts für Europäische ReCHTSGeschichte 242-43 (Helmut Coing ed., 1969).

204 Art. 44 al. 2 Dutch Commercial Code of 1838.

205 See supra, Part II.2(i).

206 Kurt Bösselmann, Die Entwicklung des deutschen Aktienwesens in 19. JahrHUNDERT 63 (1939); Deutsch, supra note 172, at 91-92; Reich, supra note 203, at 239. 
states of the German confederation abolished the Code de Commerce, while others left it in place. ${ }^{207}$ Several states also introduced or prepared corporate laws that were based on the Code de Commerce, ${ }^{208}$ including Prussia with its Stock Corporations Act of 1843.209 The latter indirectly served as the main source of inspiration for the General German Commercial Code (Allgemeines Deutsches Handelsgesetzbuch or ADHGB) of $1861,{ }^{210}$ which in turn became Germany's national corporate law (Reichsgesetz) upon its unification in 1870$71 .{ }^{211}$ As a result, the ADHGB also stipulated that the appointment of directors be revocable at any time, albeit that directors could possibly be entitled to damages. ${ }^{212}$ In addition to requiring the existence of this board (Vorstand), the ADHGB allowed the installation of a supervisory board (Aufsichtrat), ${ }^{213}$ but did not contain any prescriptions with regard to its appointment or dismissal. ${ }^{214}$

The installation of a supervisory board was rendered mandatory only by the Act of 11 June $1870 .{ }^{215}$ By the same act the requirement for government approval for the establishment of a stock corporation was abolished, ${ }^{216}$ and the supervisory board was instead mandated to control the board's management on behalf of the shareholders. ${ }^{217}$ Following another revision in

207 Deutsch, supra note 172, at 92-97.

208 Reich, supra note 203, at 243-45; Christoph Bergfeld, Aktienrechtliche Reformvorhaben vordem $A D H G B$, in 1 AKTIENRECHT IM WANDEL, supra note 163, at 168, 172, 179, $183,189$.

209 Reich, supra note 203, at 251; Erik Kießling, Das preußische Aktiengesetz von 1843, in 1 AкTienrecht im Wandel, supra note 163, at 191, 197.

210 Louis Pahlow, Aktienrecht un Aktiengesellschaft zwischen Revolution und Reichgründung. Das Allgemeine Deutsche Handelsgesetzbuch von 1861, in 1 AKTIENRECHT IM WANDEL, supra note 163, at 237, 246-48, 250.

211 KÜBleR \& Assmann, supra note 59, at 7. The code was introduced by most members of the German confederation even before its unification (Pahlow, supra note 210, at 241). A previous attempt to uniformize German corporate law failed together with the Revolution of $1848-49$ (id. at 243-45).

212 Art. 227 al. 3 ADHGB.

213 Art. 225 al. 1 ADHGB.

214 The ADHGB left the organization of its appointment to the charter (art. 209 No.7 ADHGB). The assumption that the appointment and revocation was to be made by the shareholders meeting can be deduced from art. 231 ADHGB (see Pahlow, supra note 210, at 268).

215 Art. 209 No. 6 ADHGB, as amended by Act of 11 June 1870, BGBl. 1870 1870, No. 21, 375.

216 See art. 208 ADHGB, as amended by Act of 11 June 1870.

217 Reich, supra note 203, at 267-68; Jan Lieder, Die 1. Aktienrechsnovelle vom 11. Juni 1870 , in 1 AKTienrecht im Wandel, supra note 163 , at 318, 357-58. The German legislator in 1884 reinforced this intention (Sibylle Hofer, Das Aktiengesetz von 1884 ein Lebrstück für prinzipielle Schutzkonzeptionen, in 1 AKTIENRECHT IM WandeL, 
$1884^{218}$ and in accordance with the spirit of the Code de Commerce, the ADHGB extended the rule of at will revocability to the supervisory board. ${ }^{219}$ With regard to members of the managing board though, shareholders' influence decreased. Although they continued to be removable at any time, ${ }^{220}$ the Act seemed to assume that the supervisory board decided on their appointment and removal.221 The well-known German commercial code of 10 May 1897 (Handelsgesetzbuch or $H G B)^{222}$ largely maintained pre-existing corporate law. ${ }^{223}$ As a result, it crystallized the above sketched combination of the rule of ad nutum revocability with a dual board structure and provided that the appointments of both the supervisory and the managing board were subject to revocation. ${ }^{224}$ It is only fairly recently that the principle of at will removal was curtailed in the German tradition, by the Act of 30 January 1937, which introduced the - above mentioned and qualified - requirement of a good cause for the removal of managing directors. ${ }^{225}$

Belgium, Germany and the Netherlands are thus shining examples of how thanks to Napoleon's codification and conquests the notion of mandatory ad nutum revocability spread beyond the borders of France. Obviously, the influence of Napoleon's commercial code reached far beyond the jurisdictions here examined and includes Luxembourg, Egypt, Poland, Italy, Greece, Romania, Serbia, Turkey, Brazil etc. ${ }^{226}$ Many of these seem to have similar rules

supra note 163 , at 388,412 ), after it became clear that in reality the supervisory board tended to become a governing body rather than a continuation of the shareholders meeting, under control often of the founders and later the controlling shareholder (Lieder, supra note 217, at 360-64).

218 Act of 18 July 1884, RGBl. 1884, No. 22, 123. See Reich, supra note 203, at 274-76.

219 With a three-fourths majority (artt. 191 al. 4, 224 ADHGB, as amended by Act of 18 July 1884). See Hofer, supra note 217, at 412.

220 Art. 227 al. 3 ADHGB, as amended by Act of 18 July 1884. The law continued to make a reservation for contractual indemnification obligations (id.).

221 See id. art. 225a.

222 RGBl. 1897, 219. For an English translation of the HGB of 1897, see A.F. Schuster, The German Commercial Code (1911).

223 Louis Pahlow, Das Aktienrecht im Handelsgesetzbuch von 1897, in 1 AKTIENRECHT IM WANDEL, supra note 163, at 415.

224 Art. 231 HGB stipulated that the appointment of the managing board be subject to revocation at any time, not affecting any right to indemnification from a contract. Members of the supervisory board could be revoked by the shareholders meeting pursuant to art. $243 \mathrm{HGB}$.

225 Art. 75 para. 3 Aktiengesetz of 30 January 1937, RBGl. 1937, I, 107-65; KüBLER \& Assmann, supra note 59, at 203; Walter Bayer \& Sylvia Engelke, Die Revision des Aktienrechts durch das Aktiengesetz von 1937, in 1 AkTIEnRecht IM Wandel, supra note 163, at 617, 648. This act was largely taken over in Austria. See supra, Part II. 2(i).

226 Deutsch, supra note 172, at 89. 
regarding director removal. ${ }^{227}$ This find raises the question of whether the common law legal family has an identical tradition.

\section{$V$. The Lower Significance of Revocability in Common Law}

However self-evident at will removability of corporate directors may have seemed during most of the history of civil law, it did not play as important a role in traditional common law. The absence of at will removal in old common law has often been overlooked in extant legal doctrine. An important cause might well reside in the fact that both in the United Kingdom and in the United States, the law has more recently moved in the direction of at will removal. This Part shows that at will removal was not part of the original common law, but slowly got adopted in the United Kingdom and to a lesser extent in the United States. ${ }^{228}$

\section{The United Kingdom}

In the United Kingdom, a first important step in the development of the incorporated joint stock company was made by the chartering of the English East India Company in 1600.229 The subsequent development drastically slowed down upon the passage of the Bubble Act in 1720, which severely restricted the formation of joint stock companies. ${ }^{230}$ Only when the Bubble Act was repealed in 1825 did corporate law start to develop. ${ }^{231}$ This development occurred with no discernable influence from Napoleon's Code de Commerce or civil and roman law in general. ${ }^{232}$

In the nineteenth century, English joint stock companies acts did not prescribe at will revocability of directors. At will revocability did not appear in the 1844

227 See supra, Part II.

228 For Canada, see Roger G. Bailey, Shareholder Control over Management: The Removal of Directors, 20 McGill L. J. 85, 88 (1974).

229 Paul Davies, Gower's Principles of Modern Company Law 20 (6 th $^{\text {ed. }}$ 1997); Harris, supra note 163, at 217.

230 Act of 6 Geo 1, c. 18, 1719; Bishop Carleton Hunt, The Development of the Business Corporation in England 1800-1867 (1936); Ronald Ralph Formoy, The Historical Foundations of Modern Company Law 23-29, 47-52 (1923); Ron Harris, The Bubble Act: Its Passage and its Effects on Business Organization, 54 J. Econ. Hist. 610 (1994).

231 Act of 6 Geo 4, c. 91, 1825; Davies, supra note 229, at 33-34; FormoY, supra note 230, at $52-55$.

232 Arminjon et al., supra note 183; James Willard Hurst, The Legitimacy of the Business Corporation in the Law of the United States 1780-1970, 2, 7 (1970). 
Act. ${ }^{233}$ It was introduced several years later, but merely as a default rule that appeared in the table containing model provisions applicable in the absence or silence of articles of incorporation. ${ }^{234}$ Even when these default provisions applied, at will removal still required a "special resolution" of the shareholders meeting, which implies a three-fourths majority requirement. ${ }^{235}$ Until 1948, shareholders could not dismiss directors if they could not show a good cause, and the articles of association did not provide for at will removal. ${ }^{236}$ Waiting until the end of the director's term of office and then appoint another director was not always an available solution, as directors could be appointed for life..$^{237}$

Shareholders had to wait until 1948 for the legislator to intervene. ${ }^{238}$ Since then, English law has prescribed at will removal of directors. ${ }^{239}$ Any stipulation to the contrary in an agreement between the company and a director would not stand in the way of shareholders' right to remove directors at any time. ${ }^{240}$ Yet, as in many jurisdictions on the continent, a director can have a service agreement with the company that entitles him to compensation or damages if that agreement is terminated as well. ${ }^{241}$

\section{The United States}

One would jump to conclusions too fast to assume that early American law did not feature at will revocability because early English law did not. American corporate law is to a large part indigenous and draws from English law only to a limited extent. ${ }^{242}$ At the time the first American colonies were estab-

233 Act of $7 \& 8$ Vict. c. $110,1844$.

234 See Act of 19 \& 20 Vict. c. 47, 1856 (art. 62 of table B and art. IX of the Act); Act of 25 \& 26 Vict. c. 89, 1862 (art. 65 of table A and art. XV of the Act). Table B of the Joint Stock Companies Act of 1856 had sometimes erroneously been considered as an obligatory code of rules (Henry Thring \& G.A.R. Fitzgerald, The Law and Practice of Joint-Stock and other Public Companies 252-53 (3 $3^{\text {rd }}$ ed. 1875).

235 See art. XXXIV Joint Stock Companies Act of 1856; art. LI Joint Stock Companies Act of 1862; Thring \& Fitzgerald, supra note 234, at 167.

236 Imperial Hydropathic Hotel Company, Blackpool v. Hampson (1882), 23 Ch.D. 1.

237 Laurence C.B. Gower, Modern Company Law 133 (3rd ed. 1969).

238 Paul Davies, Gower and Davies' Principles of Modern Company Law 389 (8th ed. 2008).

239 Art. 168(1) UK Companies Act of 2006.

240 DAviEs, supra note 238 , at 389.

241 Davies, supra note 238, at 392-98. The duration of a director's service contract is not to exceed two years except with approval of the shareholders meeting (art. 188 UK Companies Act of 2006).

242 Edwin Merrick Dodd, American Business Corporations Until 1860, 13-14, 195 (1954); HuRst, supra note 232, at 1, 8-9. 
lished, common law on corporations was still very incomplete and American law had to innovate a great deal. ${ }^{243}$

Still, at will revocability of corporate directors was foreign to American law as well as to English law. American jurisprudence and scholarship refers to common law as stipulating that "shareholders could remove a director only 'for cause"”. ${ }^{244}$ The same holds for legislative efforts: according to the Official Comment on MBCA $\ 8.08$, the common law position was "that directors have a statutory entitlement to their office and can be removed only for cause fraud, criminal conduct, gross abuse of office amounting to a breach of trust, or similar conduct." 245 This position was derived from "the conception that the power of directors was drawn from the statute and not solely from the shareholders". ${ }^{246}$

In the nineteenth and early twentieth century, American states increasingly regarded directors rather than shareholders as the embodiment of the corporation and continued to make it difficult for shareholders to remove directors. ${ }^{247}$ It appears that, as in the UK, more reliance was put on directors' short terms of appointment. Each time upon expiration, the stockholders meeting could refuse to reappoint a director. Massachusetts, for instance, used to have corporate law provisions on the election of directors and provided that directors remained in place until others were chosen in their stead. But it did not contain any provisions regarding removal during term. ${ }^{248}$

In 1960, at will removal was introduced as a default rule in the Model Business Corporations Act (MBCA). ${ }^{249}$ To date, the MBCA still states that "[ $\left.t\right]$ he shareholders may remove one or more directors with or without cause unless the articles of incorporation provide that directors may be removed only for cause." ${ }^{250}$ A small majority of the American states have enacted comparable

243 Pauline Maier, The Revolutionary Origins of the American Corporation, 50 WILliam \& MARY Q. 51, 52 (1993).

244 William T. Allen et al., Commentaries and Cases on the Law of Business Organization 173 (3rd ed. 2009).

2451 American Bar Association, Model Business Corporation Act Annotated 877 (4th ed. 2008).

246 American Bar Association, supra note 245, at 8-78. Nevertheless, some cases upheld charter or bylaw provisions that permitted shareholders to remove directors without cause (id. at 8-78, 8-79).

247 William G. Roy, Socializing Capital: The Rise of the Large Industrial CorPORATION IN AMERICA 156 (1997).

24844 Revised Statutes $\ 5$ (1836); 106 Public Statutes $\ 24$ (1882); 437 Business Corporation Act $\$ 18$ (1903).

249 American Bar Association, supra note 245, at 8-78, 8-79.

250 MBCA $₫ 8.08(1)$. 
provisions on director removal by stockholders and thus do not have a mandatory rule of at will revocability. ${ }^{251}$

Outside the MBCA states, there is no tendency toward imposing a mandatory rule of at will revocability either. ${ }^{252}$ The most important jurisdiction for the purpose of this study is Delaware, since the majority of American companies is incorporated in Delaware. ${ }^{253}$ Pursuant to Delaware law, directors can be removed only for cause if they are divided into classes, unless the certificate of incorporation otherwise provides. ${ }^{254}$ Most of the large public Delaware companies have a staggered board, ${ }^{255}$ the members of which can thus not be removed by the stockholders at will. A few other states have similar provisions, ${ }^{256}$ while Illinois merely allows the articles of incorporation to limit removal to cases where a cause is present when the board is staggered.257

251 Ala. Code $\$ 10 A-2-8.08$ (2011); Ariz. Rev. Stat. Ann. \$10-808 (2011); Ark. Code Ann. \$4-27-808 (2010); Colo. Rev. Stat. \$7-108-108 (2010); Conn. Gen. Stat. Ann. \33-742 (2010); Fla. Stat. Ann. \$607.0808 (2010); Ga. Code Ann. \$14-2-808 (2011); Haw. Rev. Stat. \$414-198 (2010); Idaho Code \$30-1-808 (2011); Ind. Code Ann. $\$ 23-1-33-8$ (2011); Iowa Code $₫ 490.808$ (2010); Ky. Rev. Stat. Ann. $\$ 271$ B.8-080 (2010); La. Rev. Stat. Ann. \$12:81(C)(4) (2011); Me. Rev. Stat. Ann. tit. 13-C, $\$ 808$ (2011); Mass. Gen. Laws Ann. ch. 156B, \51(a) (2010); Мich. Comp. Laws $₫ 450.1511$ (2011); Minn. Stat. Ann. \$302A.223 (2010); Miss. Code Ann. \$79-4-8.08 (2010); Mo. Ann. Stat. \$351.315 (2011); Mont. Code Ann. \$35-1-424 (2010); Neb. Rev. Stat. \$21-2085 (2010); N.H. Rev. Stat. Ann. \$293-A:8.08 (2010); N.C. Gen. Stat. \$55-8-08 (2010); N.D. Cent. Code $\$ 10-19.1-41$ (2010); Ohio Rev. Code Ann.

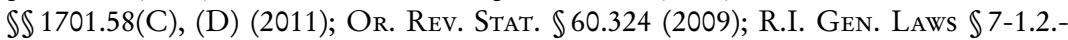
805 (2011); S.C. Code Ann. $\$ 33-8-108$ (2009); S.D. Codified Laws $\ 47-1$ A-808 (2010); Tenn. Code Ann. \$48-18-108 (2010); Utah Code Ann. \$16-10a-808 (2011); Vt. Stat. Ann. tit. 11A, $\$ 8.08$ (2010); VA. Code Ann. $\$ 13.1-680$ (2010); Wash. Rev. Code Ann. \$23B.08.080 (2011); W. VA. Code \$31D-8-808 (2011); Wis. Stat. Ann. \180.0808 (2010); Wyo. Stat. AnN. \17-16-808 (2011).

252 In addition, in several states, not only the shareholders meeting but also the board of directors can remove directors. AMERICAN BAR Association, supra note 245, at 8-84.

253 Lucian Bebchuk \& Alma Cohen, Firms' Decisions Where to Incorporate, $46 \mathrm{~J}$. L. \& Econ. 383, 389 (2003).

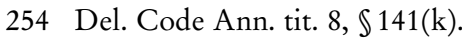

255 Bebchuk et al., supra note 11, at 895-96.

256 All of these states allow removal without cause unless the board is staggered, but they differ in the exceptions that can be made in the articles of incorporation. Some allow the articles of incorporation to provide for removability in the absence of a cause even for staggered boards (Kan. Stat. Ann. \$17-6301(k) (2009); N.M. Stat. Ann. \53-1139 (2010); OKLa. Stat. Ann. tit. 18, $\$ 1027(\mathrm{H})(2010)$ ); one allows removability without cause for corporations without staggered boards (N.J. STAT. AnN. $\mathbb{1 4 A : 6 - 6}$ (2011)); and still others allow both types of deviations, in the charter and/or bylaws (Md. Code Ann., Corps \& Ass’ns \$2-406 (2011); 15 Pa. Cons. Stat. Ann. \$1726(a)(1) (2010); Tex. Bus. Org. Code Ann. \$21.409 (2010)).

257805 Ill. Ann. Stat. 5/8.35 (2011). 
Finally, the state of New York does not allow director removal without cause unless the certificate of incorporation or the by-laws explicitly provide otherwise, ${ }^{258}$ and the District of Columbia is silent about director removal entirely. ${ }^{259}$

A mandatory rule of removability of directors without a cause is not an American thing. Only three states provide for at will removal without explicitly allowing for deviations in the articles of incorporation and/or the bylaws. ${ }^{260}$ Even in the current debate and recent initiatives with regard to strengthening shareholder power, at will removal of directors has - so far not been proposed as a means to enhance shareholders' say.

\section{Conclusion}

This article investigates through a comparative and historical analysis whether there is a general principle in European civil law regarding director removal. The investigation focuses on the circumstances in which directors can be removed from office. In particular, can shareholders oust them at will, or is there a requirement of good cause, an indemnification obligation for early termination, a waiting or notice period and/or a minimum or maximum number of directors that can be removed at once?

The analysis demonstrates that a mandatory rule of at will revocability of company directors is widespread across the civil law tradition in Europe including the French and the German and probably even the Scandinavian family. Moreover, the rule in these jurisdictions is relatively old, dating back more than two centuries to the time of the first development of corporate law. It was first laid down with general applicability in the French commercial code of 1807 and spread over Europe thanks to Napoleon's conquests and the role of his commercial code as a model for later codifications of commercial law elsewhere.

The scope of application and the intensity of the rule of at will removal of directors have decreased over time. This is for the most part due to the fairly recent introduction of two-tier boards in addition to or replacing pre-existing one-tier boards. In these new models, shareholders' say in the removal of supervisory board members has mostly not been affected. Managing directors, in contrast, can often - but not always - be removed only by the supervisory

258 N.Y. Bus. Corp. Law $\ 706$ (2011).

259 See D.C. Code Ann. \$29-101.32-33 (2011).

260 Other than adaptations for techniques such as cumulative voting and increased voting requirements such as in Nevada: Alaska Stat. $\$ 10.06 .460$ (2011); Cal. Corp. Code $\$ 303$ (2010); Nev. Rev. Stat. Ann. $\$ 78.335$ (2010). 
board. Yet, functionally speaking, in most cases the shareholders' influence continues to be felt, by cascading through their control over the supervisory board, to the level of the management board.

The history of the two chief common law jurisdictions, the United Kingdom and the United States, contrasts sharply with that of European civil law. An important finding of this article is that a mandatory rule of at will revocability is not part of the old common law. In the United Kingdom, the principle appeared early as a default rule, but it only became compulsory halfway through the twentieth century. In the United States, many states have by now introduced the rule but still allow the company to deviate in its articles of incorporation.

The findings of this article open new perspectives as well as new questions for further research. The rule of at will removal in the corporate context derives from old French civil law, ${ }^{261}$ which in turn finds much of its base in Roman law. ${ }^{262}$ An obvious question is then whether mandatory at will removability of directors can be traced back to the ius commune in its historical sense, i.e. Roman law as received on the European continent as of the Middle Ages. The findings of this article can also help us understand certain phenomena. Indeed, since at will removability of directors is crucial in determining the power relations within a corporation, a difference on this point between common and civil law presumably interacts with other divergences between both legal cultures. For instance, the finding of this difference offers support for a hypothesis I made earlier with regard to a possible association and even partially causal relationship between removability of directors and stock ownership structures. ${ }^{263}$ The possible existence of an association is to an important extent buoyed by the finding that at will removability is generally mandatory in civil law jurisdictions, where stock ownership is predominantly concentrated, but often absent or at least not compulsory in the main common law jurisdictions, where stock ownership is significantly more dispersed. The fact that the mandatory rule of at will removability traces back earlier than the development of these stock ownership patterns, moreover suggests that at least a partial causation may run from the regulation of director removal to prevailing stock ownership patterns.

The least one can say is that a longstanding difference between civil and common law with regard to the shareholders' authority to remove those in charge of governing the company is so fundamental that it is a premise absolutely to be taken into account in comparative corporate law, especially where power relations within corporations are considered.

261 See supra, Part IV.1.

262 Halpérin, supra note 172, at 69.

263 Cools, supra note 16, at 755-62; Cools, supra note 17, at 179-92. 